Електронне наукове фахове видання "Ефективна економіка" включено до переліку наукових фахових видань України з питань економіки

(Наказ Міністерства освіти і науки України від 11.07.2019 № 975) www. economy.nayka.com. ua | № 12, 2019|27.12.2019 p.

DOI: $\underline{10.32702 / 2307-2105-2019.12 .90}$

УДК 339.9

\author{
T. Shcherbyna \\ PhD in Economics, \\ Assistant Professor of International Economic Relations Department, \\ Sumy State University \\ ORCID: 0000-0001-5978-3255 \\ T. Kliushnyk \\ master student, Sumy State University \\ ORCID: 0000-0003-3143-0700
}

\title{
CHAMBER OF COMMERCE AND INDUSTRY AS AN INSTITUTE FOR ENHANCING THE DEVELOPMENT OF INTERNATIONAL TRADE IN A REGION
}

\author{
T. В. Щербина, \\ к. е. н., доцент кафедри міжнародних економічних відносин, \\ Сумський державний університет \\ T. В. Клюшник, \\ студент магістр, Сумський державний університет
}

\section{ТПП ЯК ІНСТИТУТ ПІДТРИМКИ РОЗВИТКУ МІЖНАРОДНОЇ ТОРГІВЛІ В PЕГIОНI}

The paper investigates peculiarities of functioning of the Chamber of Commerce and Industry institute in Ukraine and determines its contribution to the development of international business on the example of Sumy region. The problem raised by authors remains its relevance because of the need of entities to overcome the obstacles on the way to intensifying the international trade starting with the lack of markets peculiarities understanding, lack of experience in finding partners and opportunities, and ending with the need to meet the requirements for the quality of goods and services. The main function of CCI is to introduce business interests, including the field of international economic activity. The proving of the following services contributes in realization of international trade development promoting function: issuing certificates of origin and providing statements of goods' origin, searching for business partners, analyzing product markets, developing and supporting foreign economic agreements, determining product code, etc. It is essential to use the potential power of this organization as effective as possible. This paper underlines the importance of designing an efficient communication, service and information policy of CCI investigating theoretical, historical and practical aspects of its performance. The basic directions of Sumy CCI activity are analyzed in the context of influence on the development of international business in the region in recent years. Authors estimated the place of Sumy Chambers of Commerce and Industry in the CCI network by volume of services it performed to understand the scope of its activity in comparison with department in other regions. The range of services offered to economic entities was analyzed using the factor analysis methodology, which allowed to determine the services that are in high demand and, accordingly, make the largest contribution to 
the revenue generation. In addition, there were identified the types of activities that are not popular and examined the reasons that led to this situation. Authors suggested possible directions for problem solving, including changes in the service policy, making the member database wider through involving SMEs, improving website, etc.

У роботі досліджено особливості функиіонування інституту ТПП в Україні і визначено його внесок у розвиток міжнародного бізнесу на прикладі Сумської області. Важливість проблеми, яка підіймається авторами, обумовлена необхідністю пошуку шляхів подолання бар'єрів на шляху украӥнських компаній до міжнародних ринків, починаючи із недостатнього рівня обізнаності щзодо особливостей циільових ринків, ресурсів пошуку інформації про можливих партнерів та існуючі можливості, та закінчуючи проблемами відповідності украйнських товарів вимогам міжнародних стандартів. Основною функцією ТПП $\epsilon$ представництво інтересів бізнес кіл, включаючи $i$ сферу міжнародної економічної діяльності. Серед переліку послуг ТПП є иілий ряд тих, які напряму стосуються підтримки експортно-імпортної діяльності: надання сертифікатів походження товару, пошук партнерів закордоном, аналіз ринків, розробка та супровід міжнародних угод, визначення кодів товарів та ін. Тому дуже важливо максимально повно реалізувати можливий потенціал ї̈ впливу. Дана робота підкреслює необхідність розробки ефективної комунікаційної, сервісної та інформаційної політики ТПП через дослідження теоретичних, історичних, організачійних та практичних аспектів ї̈ діяльності. В роботі визначено основні напрямки роботи Сумської ТПП в контексті впливу на розвиток міжнародного бізнесу в регіоні за останні роки. Проаналізовано спектр послуг, які пропонуються суб'єктам господарювання, із використанням методу факторного аналізу, який дозволив виділити види діяльності, щзо користуються найбільшим попитом та, відповідно, здійснюють найбільший внесок у формування надходжень від послуг, щяо пропонує Сумська ТПП. Також визначено ті види послуг, щуо останнім часом не користуються популярністю та розглянуто причини, щуо призвели до такої ситуачії. Запропоновано можслиі напрямки вирімення проблем, включаючи удосконалення політики надання послуг та комунікаційної політики. Основною метою изього дослідження було формування орієнтирів розвитку інституту ТПП для підвищення його ролі у розвитку міжнародної економічної діяльності на регіональному рівні.

Keywords: chamber of commerce and industry; international business development; international economic activity; regional international trade enhancement; international trade; foreign investments; international economic collaboration; business internationalization.

Ключові слова: торгово-промислова палата; розвиток міжнародного бізесу; міжнародна економічна діяльність; підтримка міжнародної торгівлі в регіоні; міжнародна торгівля; прямі іноземні інвестииї; міжнародне економічне співробітництво; інтернаціоналізація діяльності.

Formulation of the problem. According to the current economic policy of Ukraine the international economic activities development is one of the priorities. Special attention is paid to the issue of export enhancement. One of the most specialized institute in this field is Chambers of Commerce and Industry. It has both functional ability and power to make a significant influence and involve domestic enterprises into the process of business internationalization. On the other hand, its potential is not utilized to full extent. That is why the problem of identifying the CCI role and finding the most efficient ways to perform are really important as it could help domestic firms to overcome existing barriers and become actors of international business.

Analysis of recent research and publications. The problem of stimulating international business development is widely discussed by researchers. In general, the activity of CCIs was investigated by S. Shuvalov, B. A. Bhuiyan, R. Meier, D. Bednařova, E. Fülöp, D. Kelly, M. Roessing, J. El-Jourbagy, U. Braendle, A. H. Rahdari, H. F. Dehkordi and others. In spite of this fact the range of researches devoted to the issue of CCI as an important actor of international business development is not really wide. Some authors describe the role of CCI as a facilitator of collaboration with foreign partners, using functional approach. Others discuss the problems of its performance in the framework of countries legislation. This 
research focuses both at developing some theoretical aspects which should be clarified to state the role of CCI in the stimulating the foreign economic activity in Ukraine, and at the efficiency of its activity.

Formulating the goals of the article. The main purpose of the paper is to identify the contribution of Chambers of Commerce and Industry to the development of international trade in a region.

Outline of the main research material. The definition of term "chamber of commerce" or "chamber of commerce and industry" can be found in many sources: web-pages of these institutions and their associations, legislative acts, scientific articles and online dictionaries, etc. Most of the definitions we analyzed were incomplete. In most cases, they contained just membership peculiarities and main purpose of the organization. However, CCI plays a significant role both in domestic and international trade development. In view of this, we want to suggest our own definition, which reflects the essence of the organization under our study in the most complete way.

Chamber of commerce and industry is an independent non-government non-profit organization which unites its members - local legal entities and individuals in business area -, represents and defends their interests providing a wide range of business services and actively cooperating with state authorities to create a more favorable business environment and promote international trade and investment activity.

The concept of chamber of commerce and industry has a long history. The first chamber of commerce emerged in Marseilles, France, in 1599. It was aimed to regulate the proceeds of tax on cargo processed at the port [1].

In Ukraine the development of CCI institute is closely connected with political strategy of the country which makes it possible to distinguish four stages of CCI development in Ukraine depending upon the status of our country on the geopolitical map of the world (tab. 1).

Table 1 - Stages of CCI institute development on the territory of modern Ukraine

\begin{tabular}{|c|c|}
\hline \multicolumn{2}{|c|}{$\begin{array}{l}\text { Stage } 1 \text { - Formation of preconditions for origination of the first institutions for facilitating the development } \\
\text { of international trade on the territory of Ukraine }\end{array}$} \\
\hline Period & 8 th century - end of 18 th century \\
\hline $\begin{array}{l}\text { Short } \\
\text { characteristic }\end{array}$ & $\begin{array}{l}\text { Trade of Eastern Slavs with merchants from East and then also with Turkic Khazar tribes } \\
\text { in 8th century, wide fame of the route "from the Vikings to the Greeks", regular fairs of local and } \\
\text { foreign goods in Lviv in 15th century were the main features of this period. }\end{array}$ \\
\hline \multicolumn{2}{|r|}{$\begin{array}{l}\text { Stage } 2 \text { - The development of CCI institute on the territory of Ukraine in the period from the end of } 18 \text { th } \\
\text { t } 1922 .\end{array}$} \\
\hline Period & end of 18 th century -1922 \\
\hline $\begin{array}{r}\text { Short } \\
\text { characteristic }\end{array}$ & $\begin{array}{l}\text { The development of industries and trade stimulated the formation of socio-economic } \\
\text { institutions. In 1801-1802 the first Contracts house was built in Kyiv and afterward - the second } \\
\text { one. The Merchant House and Merchant Assembly House were also constructed later in Kyiv. At } \\
\text { that time Halychyna and Bukovyna were part of the Austro-Hungarian Empire and the Left-Bank } \\
\text { Ukraine was part of the Russian Empire. } \\
\text { Lviv and Bukovyna CCIs became pioneers in chamber system development. In the } \\
\text { 1850s they were already actively operating. The Lviv CCI was making proposals to public } \\
\text { authorities, organizing business missions, holding agricultural exhibition etc. Bukovyna CCI was } \\
\text { a link between the government and the entrepreneurs and was serving as government advisory } \\
\text { body. It ceased its activity in } 1918 \text {. } \\
\text { On the Left-Bank Ukraine the origination of CCIs started in early 20th century. In } 1912 \\
\text { the Southwestern branch of Russian export chamber was founded in Kyiv, which had already had } \\
109 \text { members in a year after its creation. The World War I put an end to its activity. }\end{array}$ \\
\hline \multicolumn{2}{|c|}{ Stage 3 - The chamber movement in the time of the Soviet Union } \\
\hline Period & $1922-1991$ \\
\hline $\begin{array}{r}\text { Short } \\
\text { characteristic }\end{array}$ & $\begin{array}{l}\text { In } 1925 \text { the Ukrainian Western Chamber of Commerce was established in Kharkiv to } \\
\text { promote economic rapprochement with the Middle East countries. Being reorganized it was } \\
\text { liquidated in 1942. } \\
\text { In 1940s the Ukrainian Branch of All-Union Chamber of Commerce was created in } \\
\text { Kyiv. It was mainly conducting examination of goods, raw materials and equipment and creating } \\
\text { advertising products. After its reorganizations the Ukrainian Republican Branch of the All-Union } \\
\text { Chamber of Commerce was created in 1960. It started holding international exhibitions in } \\
\text { Ukraine. } 22 \text { regional bureaus and Sevastopol City Bureau of Commodity Inspection became a } \\
\text { part of the Ukrainian Branch in 1964. The Odesa and Kharkiv branches were also actively } \\
\text { developing. } \\
\text { December 15, } 1972 \text { is considered to be the official birthday of the Ukrainian Chamber of } \\
\text { Commerce and Industry. This day the Branch of the Chamber of Commerce and Industry of } \\
\text { USSR in Ukrainian SSR become the Chamber of Commerce and Industry of Ukrainian SSR. }\end{array}$ \\
\hline \multicolumn{2}{|r|}{ Stage 4 - The system of the chambers of commerce and industry of the independent Ukraine } \\
\hline Period & \\
\hline $\begin{array}{r}\text { Short } \\
\text { characteristic }\end{array}$ & $\begin{array}{l}1995 \text { was marked by the creation of regional CCIs throughout the } \\
1997 \text { the chambers system got legislative support - the law "On Chamb }\end{array}$ \\
\hline
\end{tabular}




\begin{tabular}{|l|l|}
\hline $\begin{array}{l}\text { Industry in Ukraine" was adopted. In } 1998 \text { there were } 26 \text { regional chambers of commerce in } \\
\text { Ukraine. They became an important factor of international economic relations development. } \\
\text { The further rapid development made the CCI system influential, active, effective and the }\end{array}$ \\
$\begin{array}{l}\text { most regionally branched organization in Ukraine. Today it cooperates with a powerful network } \\
\text { of partners abroad creating favorable business conditions, facilitating the increase of business } \\
\text { competitiveness. Currently the CCI system unites more than } 8 \text { thousand of members in } 25 \text { regions } \\
\text { of Ukraine. }\end{array}$
\end{tabular}

Source: created by the authors on the basis of [2, 3, 4, 5]

So, over time, the role of CCI institution in the development of international trade was increasing. In the modern Ukraine, according to the Law of Ukraine "On Chambers of Commerce and Industry in Ukraine" of December 2, 1997, the main purpose of CCI creation is "facilitating development of businesses and national economy, its integration into the world economic system, formation of modern industrial, financial and trade infrastructures" [6].

We propose to consider the current role of this organization in Ukraine in more detail by example of Sumy CCI. Today it provides a wide range of business services, including the following ones: 1) issuing certificate of origin and providing statement of goods' origin; 2) executing commodity examination, examination, related to operations with raw materials that were processed in the customs territory of Ukraine, examination on witnessing commercial documents, examination on determining product or service code; 3 ) preparing reference about the enterprise, prices and factographic references; 4) searching for a business partner, analysing product market, developing and supporting foreign economic agreement; 5) services in the field of public procurement and intellectual property rights protection; 6) informational services; 7) conference service and many other. The number of the most popular services that were provided by this organization over the last three years is represented on figure 1.
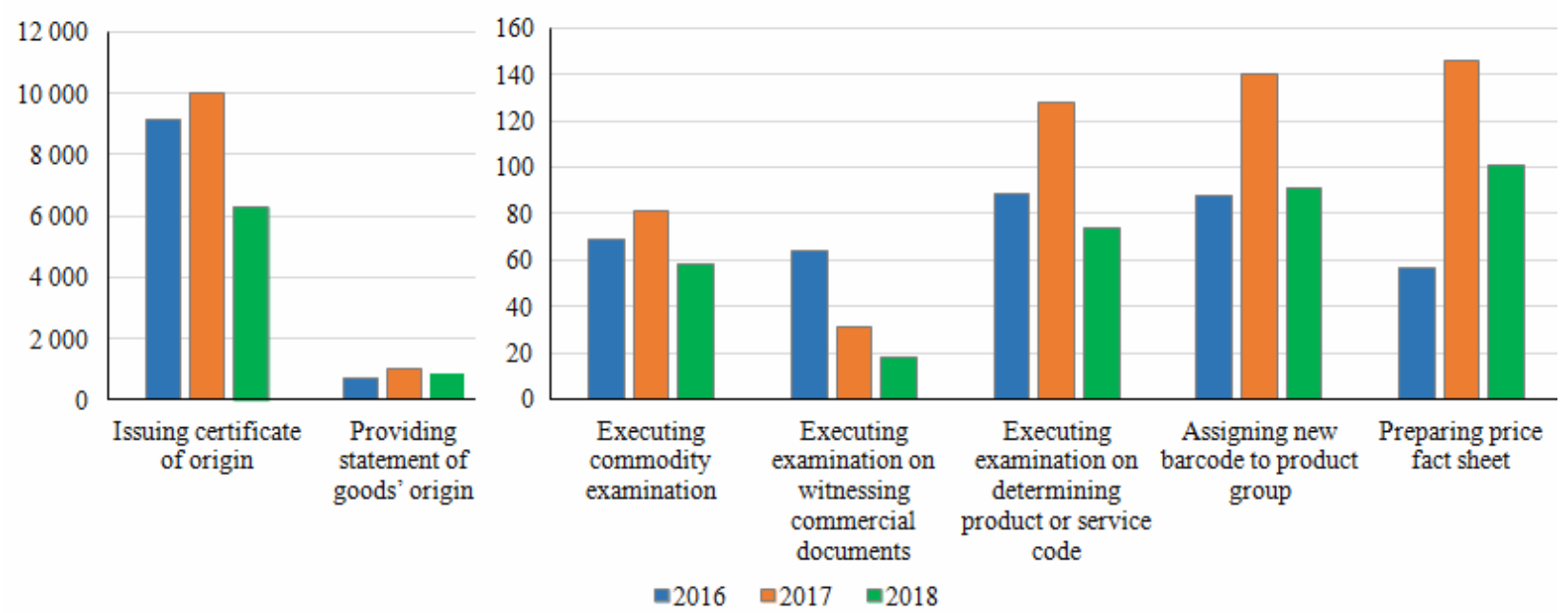

Figure 1 - Volumes of services provided by Sumy CCI in 2016-2018, units [6, 7, 8]

Effective realization of CCI functions requires a certain organizational and management structure. The line and staff structure has formed in the Sumy CCI (fig. 2). It is characterized by a wide range of advantages: ensuring a clear operation of each subsystem as well as the whole organization in general due to a rigid communication system, forming a mechanism for competent decision making by providing managers with qualified information from lower level specialists etc. $[10,11]$. 


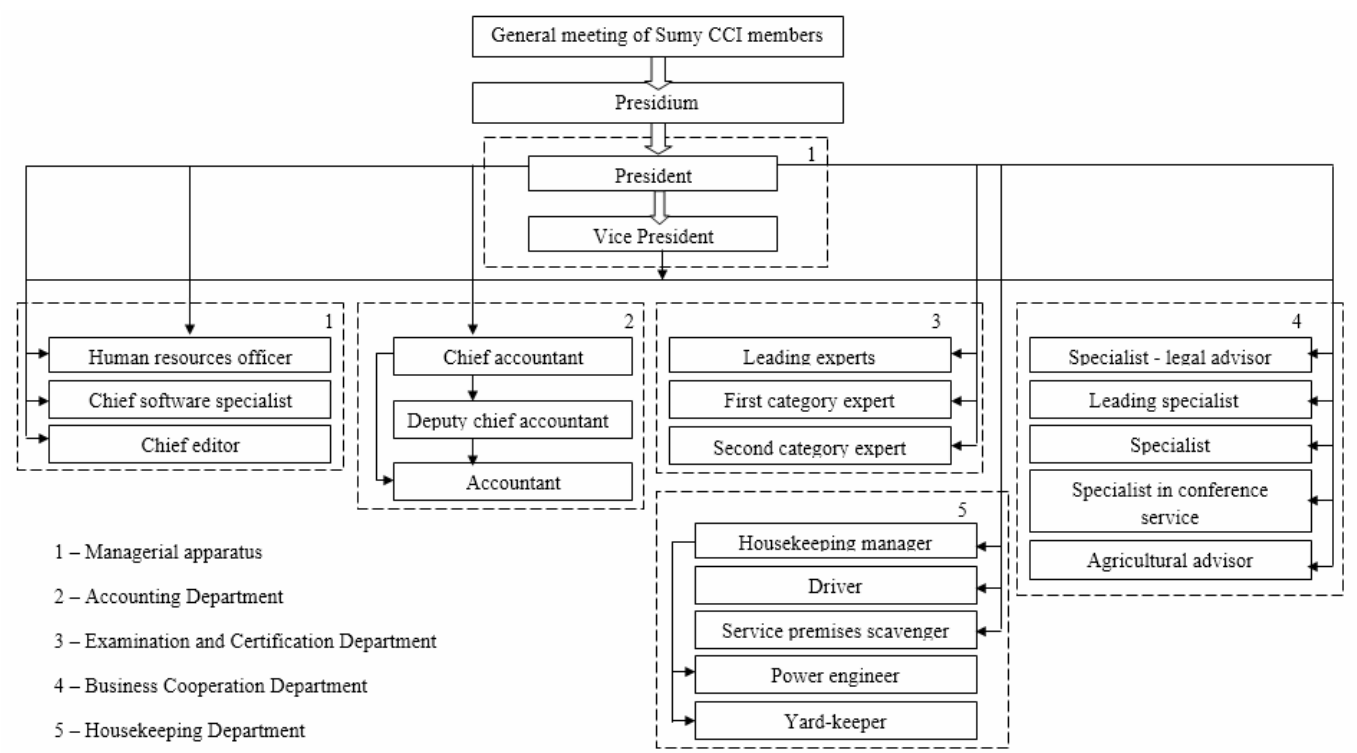

Figure 2 - Organizational and management structure of the Sumy CCI

In addition to providing mentioned above services, an important function of the Sumy CCI is the organization of business events. In 2016-2018 the Sumy CCI has held from 9 to 10 events for the representatives of business circles annually. The number of participants they attracted amounted to 378 people in 2016, 680 - in 2017 and 665 - in 2018. On average, $70 \%$ of the events organized by this institution were aimed to develop foreign economic activity in the Sumy region or highlighted this issue in one of their topics. Their participants constituted $82.3 \%, 50.4 \%$ and $66.9 \%$ of the general number of participants of events organized by Sumy CCI in 2016, 2017 and 2018 respectively [6, 7, 8].

Due to this kind of Sumy CCI's activity the local representatives of business circles have discussed or got to know the following information important for conducting international trade: modern methods of development and implementation of export sales system; peculiarities of conducting safe export activity; potential barriers to entering EU markets for Sumy region enterprises in the field of mechanical and electrical engineering; peculiarities of marketing activity in the markets of Arab countries, business culture and business etiquette in the region, protecting the interests of Ukrainian entrepreneurs in these countries; prospects for the development of international and economic cooperation between Sumy region and the Republic of Macedonia and further cooperation with the Republic of India; procedures for facilitating international trade and access to information, trade defense instruments under international agreements; features of organic products export, requirements and procedures; quality requirements for honey supplied to the EU market; prospects of export to Canada for agribusiness, light industry and furniture producers; promotion of Ukrainian products in China and Vietnam; opportunities for companies to participate in EU grant programs etc.

Besides that, informational support is provided by the Sumy CCI through its "Dilovi novyny" magazine, weekly newsletter, publications, photo and video reports on its web-page and page in Facebook. The members of this organization also receive commercial offers and offers for cooperation from foreign companies due to targeted sending them by e-mail.

It is worth saying that in 2016-2018 the Sumy CCI has organized 8 business missions that helped the representatives of Sumy region business circles to make contacts and start cooperating with enterprises of Belarus, China, Poland, Macedonia. Business mission is one of the most important elements for supporting and developing business and a great opportunity to make business contacts and present enterprise's products abroad.

In general, over the three explored years the Sumy CCI has realized services in the amount of 19299.7 UAH, and almost $65 \%$ of this sum was gained due to providing services on certification of origin and belonging to own production. In 2018 the CCI earned $60.96 \%$ more income than in $2016[6,7,8]$.

The Sumy CCI is on the 20th place in the rating of Ukrainian CCIs in terms of volume of services provided for 10 months of 2019 (fig. 3). The share of the Sumy CCI in the formation of the total income of the system of Ukrainian CCIs from providing services for specified period amounts to $1.64 \%$. It is lower than an average value of this indicator which is $3.85 \%$. This indicator is significantly influenced by the number of CCI's members. The Sumy CCI is ranked 22nd in the rating of regional CCIs in Ukraine according to the size of the membership base (fig. 4). 


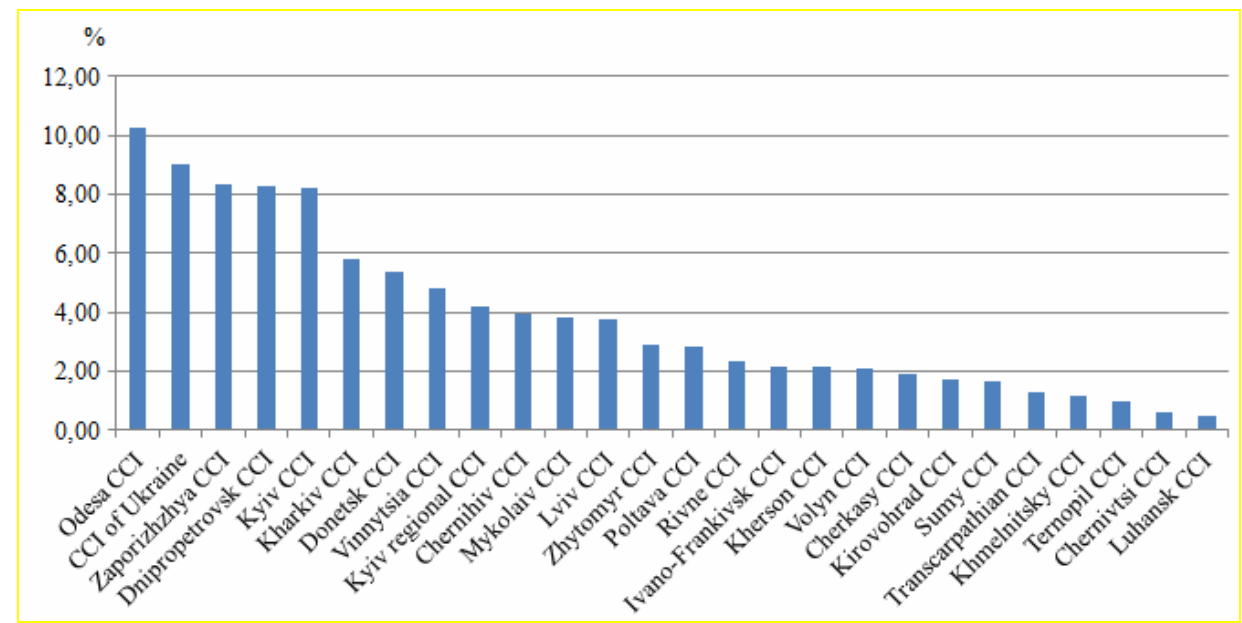

Figure 3 - The rating of Ukrainian CCIs in terms of volume of services provided for 10 months of 2019 [13]

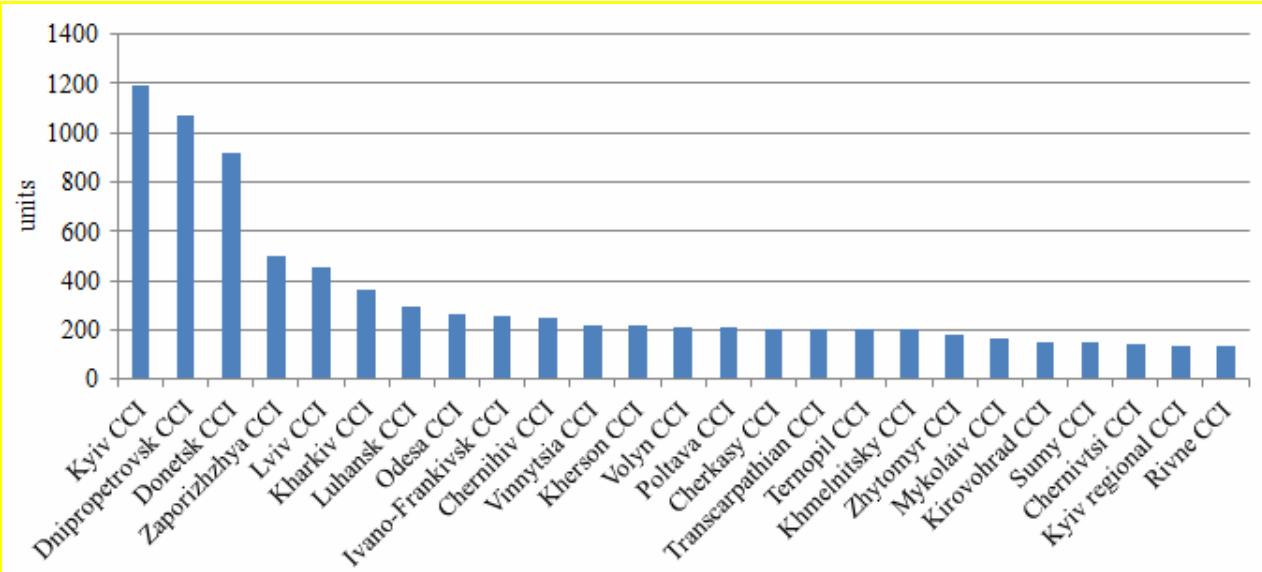

Figure 4 - The rating of regional CCIs in terms of the number of members in 2019

In order to determine the services which provided the biggest growth of income in 2018, we have applied factor analysis. The results of the conducted analysis are represented in figure 5.

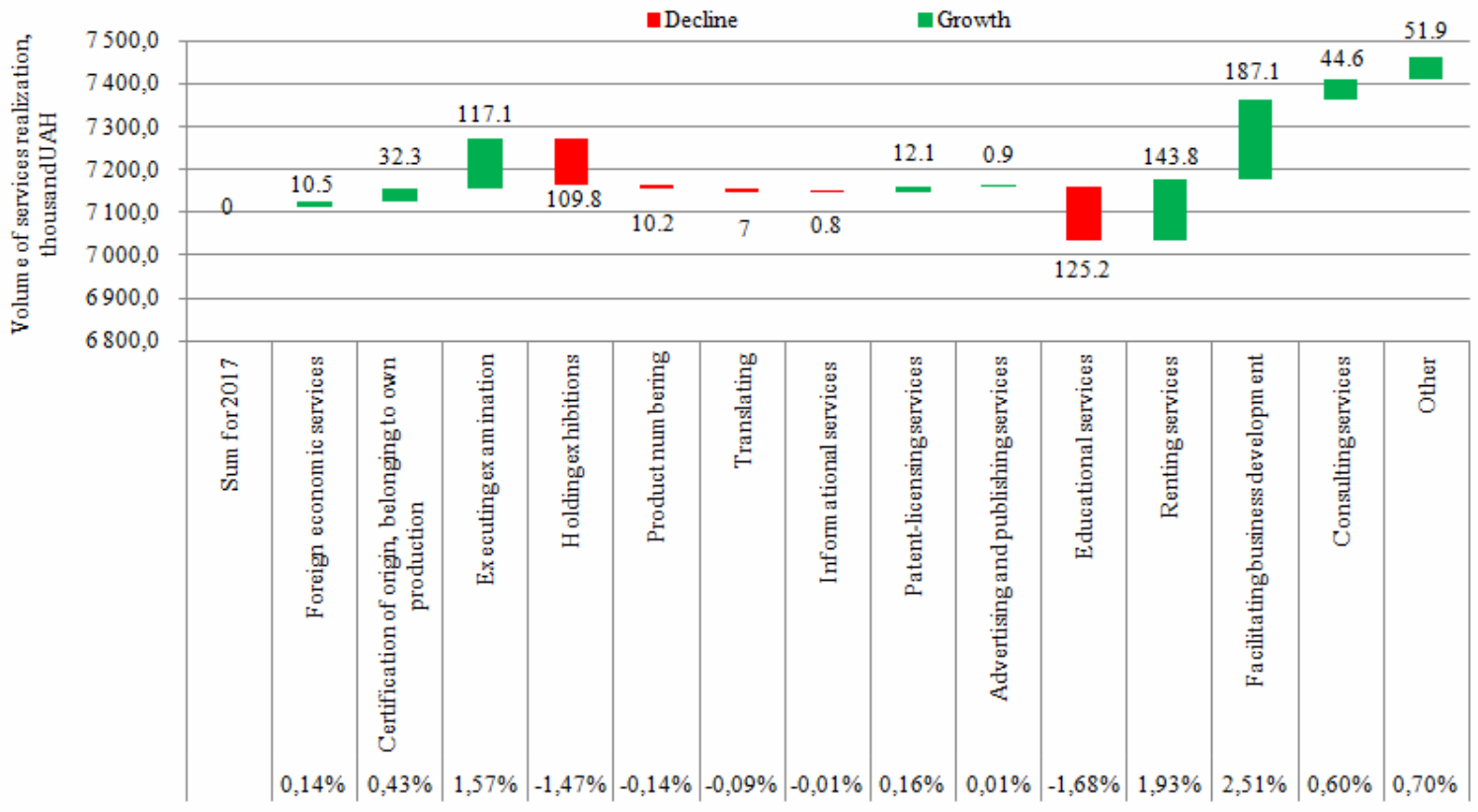

Figure 5 -Services provided by the Sumy CCI in 2016-2018 


\section{Conclusions}

To conclude, one of the most important functions of CCIs in Ukraine, in particular Sumy CCI, is promoting the international trade development. The proving of the following services contributes in realization of this function: issuing certificates of origin and providing statements of goods' origin, searching for business partners, analyzing product markets, developing and supporting foreign economic agreements, determining product code, etc.

Besides that, this organization actively improves the level of local enterprises' knowledge in this field by holding business events, helps entrepreneurs in making business contacts with foreign partners due to organizing business missions, provides informational support of its members through publications in "Dilovi novyny" magazine and weekly newsletters, on its web-page and page in Facebook.

Some services have not become popular among representatives of Sumy region business circles yet, while some of them, in particular certificates of origin and statements of goods' origin, are very demanded and in 2016-2018 have been ordered 25470 times and 2595 times respectively. Many CCI's services decreased in terms of volumes of realization in 2018. But taking into account the specificity of this institution activity, we can say that the amount of orders does not depend upon its workers, but fluctuates according to the state of economy, state policy and the needs of local enterprises and organizations. For example, in 2018 the volume of this service providing decreased by $30.98 \%$ and $36.68 \%$ comparing with 2016 and 2017 respectively. The most important reason for this decrease was the fact that since 2018 the preferential certificates of origin for export to EU countries were issued only by customs offices.

In general, in 2018 the Sumy CCI has improved the financial indicator of its activity - increased the income from providing services. According to the results of factor analysis the main engines for this growth were the services on facilitating business development, renting services and services on executing examination. At the same time the major decline of this indicator was caused by two groups of services: educational (mainly training in the field of public procurement) and holding exhibitions. The number of seminars on public procurement decreases because of competition, financial problems of enterprises that did not allow them to finance trainings for employees, besides that, a lot of companies preferred to outsource services on public procurement than educate the workers. The decline of incomes from holding exhibitions was caused by small demand, unprofitability of this activity because of big material and technical costs and a likelihood of opening another exhibition area in Sumy which led to reorientation of the first floor of the Illinskyi Exhibition Center for renting by shops and holding mainly small exhibitions or abroad.

Taking into account all the above-mentioned information, we consider it expedient to advertise the services on searching for a business partner, analyzing the product market, developing and supporting foreign economic agreements more actively using not only Sumy CCI's information channels, but also other printed and internet resources. It will be also effective to provide these services free of charge while the base of positive results will not be formed. Such successful examples of enterprises which, for example, have concluded contracts for the supply of significant consignments of goods with the partners found by the Sumy CCI, will be a good basis for attractive advertisement.

In order to improve situation with educational services it is important to expand the directions of this activity in order to attract more listeners. For example, we offer to introduce seminars on different types of quality certification, taking part in grant programs, etc.

\section{References.}

1. Svit uspikhu (2012), Torhovo-promyslova palata Ukrainy. 40 rokiv. Istoriia u mnozhyni [Chamber of Commerce and Industry of Ukraine. 40 years. Plural history], Svit uspikhu, Kyiv, Ukraine

2. Skrypchenko, S. (2003), "Chambers of Commerce and Industry as the drivers of economic growth", [Online], Dilovyj Visnyk, vol. 10(113), available at: http://old.ucci.org.ua/synopsis/dv/2003/dv0310021.ua.html (Accessed 10 Dec 2019).

3. Skrypchenko, S. (2001), "Independent Ukraine - 10 years”, Dilovyj Visnyk, [Online], Vol. 8(87), available at:http://old.ucci.org.ua (Accessed 10 Dec 2019).

4. The official site of Sumy Chambers of Commerce and Industry (2019), available at: https://ucci.org.ua

5. The Verkhovna Rada of Ukraine (1998), The Law of Ukraine "On Chambers of Commerce and Industry in Ukraine", available at: https://zakon.rada.gov.ua/laws/anot/en/671/97-\%D0\%B2\%D1\%80/sp:head (Accessed 10 Dec 2019).

6. Sumy Chamber of Commerce and Industry (2017), Zvit pro robotu Sums'koi torhovo-promyslovoi palaty za 2016 rik. [Report on the performance of the Sumy Chamber of Commerce and Industry 2016], Sumy Chamber of Commerce and Industry, Sumy, Ukraine.

7. Sumy Chamber of Commerce and Industry (2018), Zvit pro robotu Sums'koi torhovo-promyslovoi palaty za 2017 rik. [Report on the performance of the Sumy Chamber of Commerce and Industry for 2017], Sumy Chamber of Commerce and Industry, Sumy, Ukraine.

8. Sumy Chamber of Commerce and Industry (2019), Zvit pro robotu Sums'koi torhovo-promyslovoi palaty za 2018 rik. [Report on the performance of the Sumy Chamber of Commerce and Industry for 2018], Sumy Chamber of Commerce and Industry, Sumy, Ukraine. 


\section{Список використаних джерел.}

1. Торгово-промислова палата України. 40 років. Історія у множині. - К.: Світ успіху, 2012. - 352 с.

2. "Торгово-промислові палати - рушії економічного зростання" [Електронний ресурс] // ДІЛОВИЙ ВІСНИК. - 2003. - №10(113). - Режим доступу до pecypcy: http://old.ucci.org.ua/synopsis/dv/2003/ dv0310021.ua.html.

3. Скрипченко С. Незалежній Україні - 10 років [Електронний ресурс] / С. Скрипченко // ДІЛОВИЙ ВІСНИК. - $2001 . \quad$ - $\quad №$ 8(87). -2 Режим доступу до ресурсу: http://old.ucci.org.ua/synopsis/dv/2001/dv0108011.ua.html.

4. Офіційний сайт Торгово-промислової палати України [Електронний ресурс]. - Режим доступу : https://ucci.org.ua/.

5. The Law of Ukraine "On Chambers of Commerce and Industry in Ukraine" of January 5, 1998 [Electronic resource]. - Access mode: https://zakon.rada.gov.ua/laws/anot/en/671/97-\%D0\%B2\%D1\%80/sp:head.

6. Звіт про роботу Сумської торгово-промислової палати за 2016 рік.

7. Звіт про роботу Сумської торгово-промислової палати за 2017 рік.

8. Звіт про роботу Сумської торгово-промислової палати за 2018 рік.

Стаття надійшла до редакиіï 19.12.2019 p. 